\title{
Seasonal changes of chemical composition in boreonemoral moss species
}

\author{
Laura Klavina ${ }^{1 *}$, Gunta Springe' ${ }^{1}$ Iveta Steinberga', Anna Mezaka', Gederts levinsh ${ }^{2}$ \\ ${ }^{1}$ Department of Environmental Science, University of Latvia, Raina Bulvaris 19, Riga LV-1586, Latvia \\ ${ }^{2}$ Faculty of Biology, University of Latvia, Jelgavas 1, Riga LV-1004, Latvia \\ ${ }^{*}$ Corresponding author, E-mail: laura.klavina@lu.lv
}

\begin{abstract}
Bryophytes have been more and more studied, due to presence of many biologically active compounds among their secondary metabolites, unique drought resistance as well as due to their wide use as bioindicators of environmental pollution. The aim of the present study was to determine seasonal changes in chemical composition and composition of secondary metabolites in four moss species (Sphagnum fallax, Sphagnum magellanicum, Polytrichum juniperinum, and Pleurozium schreberi). Concentration of main groups of chemical constituents as well as antioxidant activity were determined and related to climate parameters (temperature, precipitation etc.) during two vegetation seasons. Dependence of both primary and secondary metabolism on climatic conditions was confirmed. Seasonal changes of 57 secondary metabolites reflected species-specific features. The pattern of seasonal changes of major groups of moss secondary metabolites was determined, allowing selection of the best timing for bioprospecting studies as well as for use as possible indicators of environmental stress.
\end{abstract}

Key words: bryophytes, GC-MS, mosses, seasonal changes, secondary metabolites, sterols.

Abbreviations: GC-MS, gas chromatography-mass spectrometry; DPPH, 2,2-diphenyl-1-picrylhydrazyl.

\section{Introduction}

Mosses are important elements of ecosystems, especially in the northern regions of Earth, where they are the main peat forming plant (Sphagnum mosses). The major structural components of mosses are carbohydrates (Maksimova et al. 2014; Klavina 2015). They contain also a high number of different secondary metabolites, most of them with not clear metabolic function, but with possibly high biological activity (Asakawa et al. 2013). Secondary metabolites in mosses can be different from those in higher plants (Goffinet, Shaw 2008), but their composition has not been much studied from the perspectives of their practical application potential and functional significance.

Considering practical aspects, there is a growing interest on bryophyte chemical composition due to presence of a high number of biologically active compounds (Cheng et al. 2012; Fu et al. 2012; Asakawa et al. 2013). Bryophytes were considered as almost useless for humans as a source of biologically active substances, and have been neglected for a long time due to their small size and identification problems. However recent studies have demonstrated that many compounds isolated from bryophytes have high biological activity (Krzaczkowski et al. 2009; Üçüncü et al. 2010; Cheng et al. 2012), and thus extracts of bryophytes are prospective for search of new pharmaceutically active compounds (Wang et al. 2005; Asakawa 2007). Still from a large number of bryophytes only a negligible number of species have been extensively studied and most recent studies have concentrated on chemical composition of liverworts and especially on substances present in oil bodies of these plants (Asakawa et al. 2013).

From a functional point of view, different secondary metabolites can have adaptive roles in moss tissues. Therefore, studies of these compunds will help to understand responses to evironmental heterogeneity (drought/ wetness), impact of UV radiation, protection against oxidative stress due to pollution, as well as functions of the main secondary metabolites in the overall metabolism (Tutschek 1979; Goffinet, Shaw 2008; Xie, Luo 2009; Huang et al. 2012). Many of the mentioned factors have a clear seasonal pattern (temperature, amount of precipitations, solar radiation etc.) and thus studies of seasonal changes of secondary metabolites in mosses can give insight into regulation and functional roles of key substances in moss metabolism. Impact of seasonal changes of vegetation until now has been studied regarding example of impacts on lipid composition in Sphagnum mosses (Karunen, Salin 1982; Huang et al. 2012) as well as accumulation of certain chemical elements (Boquette et al. 2011).

The aim of the present study was to determine seasonal changes of chemical composition and concentration of particular metabolites in moss tissues growing in a swamp forest. For comparison, four typical moss species 
(Sphagnum fallax, Sphagnum magellanicum, Polytrichum juniperinum, Pleurozium schreberi) were selected.

\section{Materials and methods}

\section{Study area}

Phenological data were collected in a swamp forest located in Central Latvia geobotanical region, Sērene district, Jaunjelgava region, south-central part of Latvia (Fig. 1), where annual rainfall is 500 to $700 \mathrm{~mm}$, average temperature in January 5 to $6{ }^{\circ} \mathrm{C}$, in July 16.5 to $17.0^{\circ} \mathrm{C}$. Southern, south-western, western winds are dominating in Latvia. The annual relative humidity is $81 \%$. Data of the climatic parameters (air temperature, amount of precipitation and intensity of solar radiation) were obtained from the Latvian Centre for Environment, Hydrometeorology and Geology.

The studied forest stand was 60 years old, area 7.30 ha, with Pinus sylvestris in the overstory. Snags, dead wood, including logs of different sizes, uprooted wind falled trees were characteristic in the studied site. The forest stand topography was structured as a hummock-hollow complex. Understory cover consisted of trees Picea abies, Betula pubescens, dwarf shrubs on hummocks (Vaccinium myrtillus, Ledum palustre, Andromeda polyfolia, Oxycoccus palustris), bryophytes (Pleurozium schreberi, Polytrichum juniperinum, Sphagnum angustifolium, Sphagnum magellanicum), cottongrass Eriophotum vaginatum, and bryophytes in hollows Sphagnum fallax. On the forest stand margins dwarf shrub Vaccinium uliginosum, and bryophytes Hylocomium splendens and Ptilium cristacastrensis were also found.

\section{Sample collection}

Moss species [Sphagnum fallax H. Klinggr., Sphagnum magellanicum Brid., Polytrichum juniperinum Hedw., Pleurozium schreberi (Willd. ex Brid.) Mitt.] samples were collected in swamp forest, Sērene parish, Jaunjelgava municipality, south-central part of Latvia during the vegetation season from April till October in 2014 and 2015. Sampling sites were selected based on proximity of transport and representativeness close to natural conditions of the forest stand. Bryophytes were sampled ( $10 \mathrm{~g})$ every two weeks. Each sample was placed in closed plastic bag. Samples were brought to laboratory for chemical analysis as soon as possible. In some cases bryophyte samples were kept in a refrigerator (not longer than a week) before transportation to laboratory.

\section{Lipid extraction}

Dry (dried at $40{ }^{\circ} \mathrm{C}$ until constant mass) moss samples were ground in a mill, $1 \mathrm{~g}$ of sample was placed in a $100 \mathrm{~mL}$ bottle with a screw cap, $50 \mathrm{~mL}$ of chloroform was added. Samples were exposed to ultrasound $(100 \mathrm{~W})$ in an ultrasound bath (Cole Parmer) for $40 \mathrm{~min}$. The temperature was kept constant at $40{ }^{\circ} \mathrm{C}$ by regularly adding cold water. Bottles were shaken in a shaker for $24 \mathrm{~h}$ at $140 \mathrm{rpm}$. After that 40 min treatment with ultrasound was repeated. Extracts were filtered and concentrated on a rotation evaporator.

\section{Analysis of lipid extracts by gas chromatography-mass spectrometry}

Extract samples (20 mg DM) were placed in glass vessels. Dry residue was dissolved in $1.4 \mathrm{~mL}$ acetonitrile, 0.5 $\mathrm{mL}$ inner standard and $0.1 \mathrm{~mL} \mathrm{~N}, \mathrm{O}-$ bis(trimethylsilyl) trifluoroacetamide reagent. The vessel was tightly sealed and heated at $60{ }^{\circ} \mathrm{C}$ for an hour. In order to ensure that all reagent has reacted, $0.01 \mathrm{~mL}$ methanol was added to the mixture. After cooling at room temperature, the glass vessel with the mixture was used for gas chromatographymass spectrometry (GC/MS) analysis. The GC-MS instrumentation consisted of a Clarus 680 chromatograph and a Clarus SQ $8 \mathrm{C}$ mass spectrometer. The separations were performed on a Elite-5ms (5\% phenyl and 95\% methyl polysiloxane) capillary column $(30 \mathrm{~m} \times 0.25 \mathrm{~mm}$

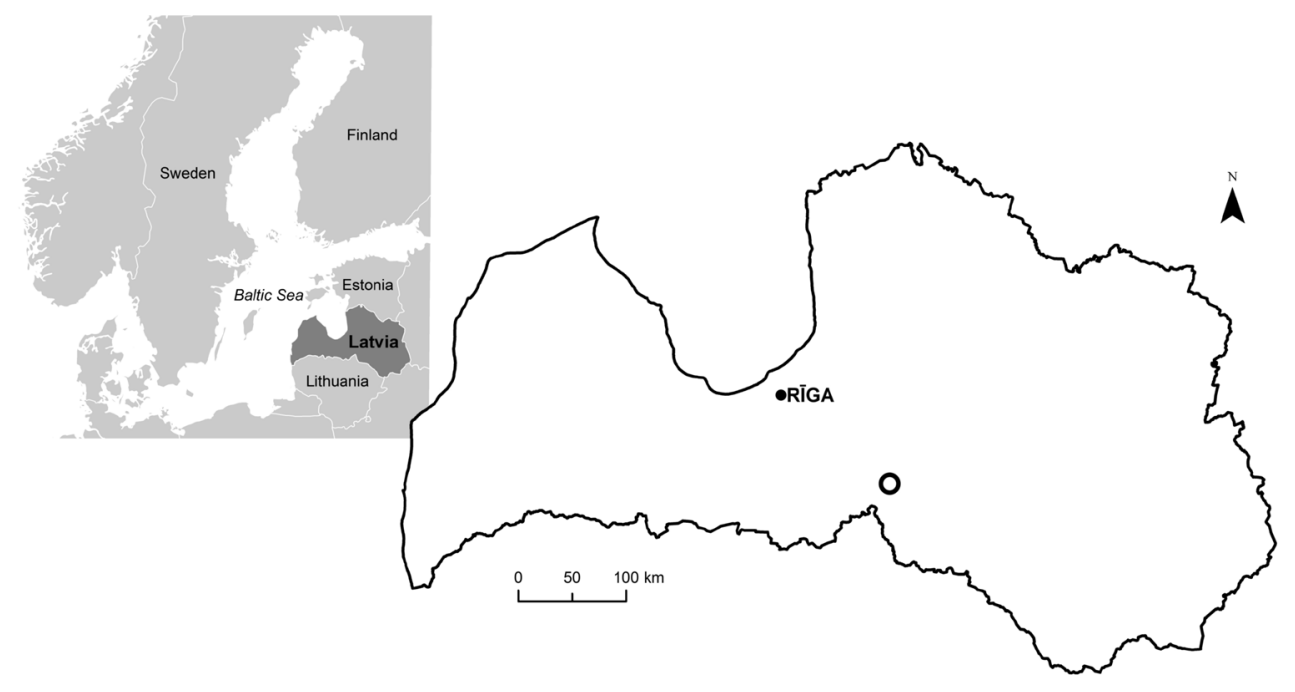

Fig. 1. Location of the sampling station (marked with a circle). 
i.d., $0.25 \mu \mathrm{m}$ film thickness). Helium (99.9999\%) was used as a carrier gas at initial flow $2.0 \mathrm{~mL} \mathrm{~min}{ }^{-1}$ for $2 \mathrm{~min}$ and subsequently held constant at $1.0 \mathrm{~mL}$ with split flow 10.0 $\mathrm{mL} \mathrm{min}^{-1}$. Column temperature was maintained at $75{ }^{\circ} \mathrm{C}$ for $2 \mathrm{~min}$, then arised from 75 to $130{ }^{\circ} \mathrm{C}$ at $20^{\circ} \mathrm{C} \mathrm{min}{ }^{-1}$ and from 130 to $310{ }^{\circ} \mathrm{C}$ at $4{ }^{\circ} \mathrm{C} 1 \mathrm{~min}^{-1}$, and finally held at $310^{\circ} \mathrm{C}$ for $12 \mathrm{~min}$; total run time was $59.25 \mathrm{~min}$. The $1.0 \mu \mathrm{L}$ sample was injected in a split mode injector $(4 / 1)$ with an autosampler. The mass spectrometer was operated in electron impact mode at $70 \mathrm{eV}$ ionization energy and was scanned from 42 to $650 \mathrm{Da}$ with a cycle time $0.5 \mathrm{~s}$. The multiplier was operated at $1700 \mathrm{~V}$. Column injector and transfer line temperatures were 290 and $250^{\circ} \mathrm{C}$, respectively, and ion source temperature was $230^{\circ} \mathrm{C}$. Retention time (Rt, $\mathrm{min}$ ) and mass spectrometry fragmentation patterns of the known compounds were compared with literature and the database NIST (Pejin et al. 2011). All peaks were quantified by peak area.

\section{Extraction of polyphenols and carbohydrates}

Samples were dried at $40{ }^{\circ} \mathrm{C}$ in an oven until constant mass. Dry samples were ground in a mill, and a $1 \mathrm{~g}$ moss sample was placed in a bottle with a screw cap, adding 50 $\mathrm{mL} 60 \%$ aqueous ethanol solution. Samples were exposed to ultrasound $(100 \mathrm{~W})$ in an ultrasound bath (Cole Parmer) for $40 \mathrm{~min}$. Temperature was kept constant at 40 ${ }^{\circ} \mathrm{C}$ by regularly adding cold water. Bottles were shaken in a shaker for $24 \mathrm{~h}$ at $140 \mathrm{rpm}$. After that $40 \mathrm{~min}$ treatment with ultrasound was repeated. Extracts were filtered and concentrated on a rotation evaporator.

\section{Analysis of total polyphenol concentration}

For determination of total amount of polyphenols the FolinCiocalteu reagent was used (Singleton et al. 1999). Before analysis, moss extracts were kept at room temperature for $\sim 1 \mathrm{~h}$, then $1 \mathrm{~mL}$ moss extract was added to a test tube and 5 $\mathrm{mL}$ 10\% Folin-Ciocalteu reagent (Aldrich) was added; after $5 \mathrm{~min}, 4 \mathrm{~mL}$ 7.5\% sodium carbonate (Aldrich) was added. The test tube was shaken thoroughly and kept in a dark place in room temperature for $2 \mathrm{~h}$. Absorption was measured in a quartz cuvette $(\mathrm{d}=1 \mathrm{~cm})$ on a spectrophotometer (Hach-Lange DR 2800) at $725 \mathrm{~nm}$ wavelength. Results were calculated using a standard curve and expressed as gallic acid equivalents (GE) per $100 \mathrm{~g}$ dry matter (Singleton et al. 1999; Silverstein et al. 2005). Three parallel measurements were performed.

\section{Analysis of total carbohydrate concentration}

Before analysis, moss samples were kept at room temperature for $\sim 1 \mathrm{~h}$. In a test tube $0.1 \mathrm{~mL}$ extract was diluted to $1 \mathrm{~mL}$ with deionized water. Then $1 \mathrm{~mL}$ of $5 \%$ phenol (Aldrich) solution was added and rapidly $5 \mathrm{~mL}$ of concentrated sulphuric acid (Aldrich) was added. After 10 min the test tubes were carefully shaken and were left for 20 min at room temperature. Absorption was measured with a spectrophotometer (Hach-Lange DR 2800) at $490 \mathrm{~nm}$. Three parallel measurements were performed. Carbohydrate concentration was determined with a calibration curve using glucose solution as a standard (Narwal et al. 2011).

\section{Analysis of radical scavenging activity by 2,2-diphenyl-1- picrylhydrazyl}

Before analysis, moss samples were kept at room temperature for $\sim 1 \mathrm{~h}$. In a test tube $0.3 \mathrm{~mL}$ moss extract was mixed with $3.6 \mathrm{~mL} 4 \%$ 2,2-diphenyl-1-picrylhydrazyl (DPPH) (Aldrich) in 96\% ethanol. The mixture was incubated for $20 \mathrm{~min}$ in darkness at room temperature. Absorption was measured in a quartz cuvette $(\mathrm{d}=1 \mathrm{~cm})$ with a spectrophotometer (Hach-Lange DR 2800) at $517 \mathrm{~nm}$ wavelength. Three parallel measurements were performed. Radical scavenging activity was expressed as percentage of inhibition DPPH free radical.

\section{Analysis of flavonoid concentration}

Before analysis, moss samples were kept at room temperature for $\sim 1 \mathrm{~h}$. In a test tube $1 \mathrm{~mL}$ moss extract was mixed with $1 \mathrm{~mL} 20 \%$ aluminium oxide (Aldrich). The mixture was incubated for $1 \mathrm{~h}$ in darkness at room temperature. Absorption was measured in a quartz cuvette $(\mathrm{d}=1 \mathrm{~cm})$ with a spectrophotometer (Hach-Lange DR 2800) at $415 \mathrm{~nm}$ wavelength. Three parallel measurements were performed. Flavonoid content was determined with a calibration curve using quercetin dihydrate as a standard (Mitrovič et al. 2011).

\section{Data analysis}

Statistical analysis was doneusing IBM SPSS (ver. 22.). Linear correlation analysis was performed to determine relationship between changes of climatic parameters and composition indicators of the studied mosses during the study period.

\section{Results}

The study period had weather typical for Northern Europe/ Baltic region with relatively rapidly changing weather conditions. In 2014, periods up to two weeks of relatively dry climate with intensive solar irradiation (April 15 to 29; May 13 to June 3; July 1 to 29) were characteristic, changing to periods with intensive precipitation (April 29 to May 13; June 10 to July 1; July 29 to August 26; Fig. 2A). In 2015, the pattern of weather conditions was more even and dry (Fig. 2B). Wet periods changed more frequently and simultaneous impact of heat and wetness was less probable.

Considering the significance in physiological processes, total concentrations of carbohydrates and polyphenols were analysed. During the study period significant fluctuations were observed in concentration of both carbohydrates and polyphenols (Fig. 3) indicating their elevated sensitivity to climatic conditions. During 2014 in a period of 

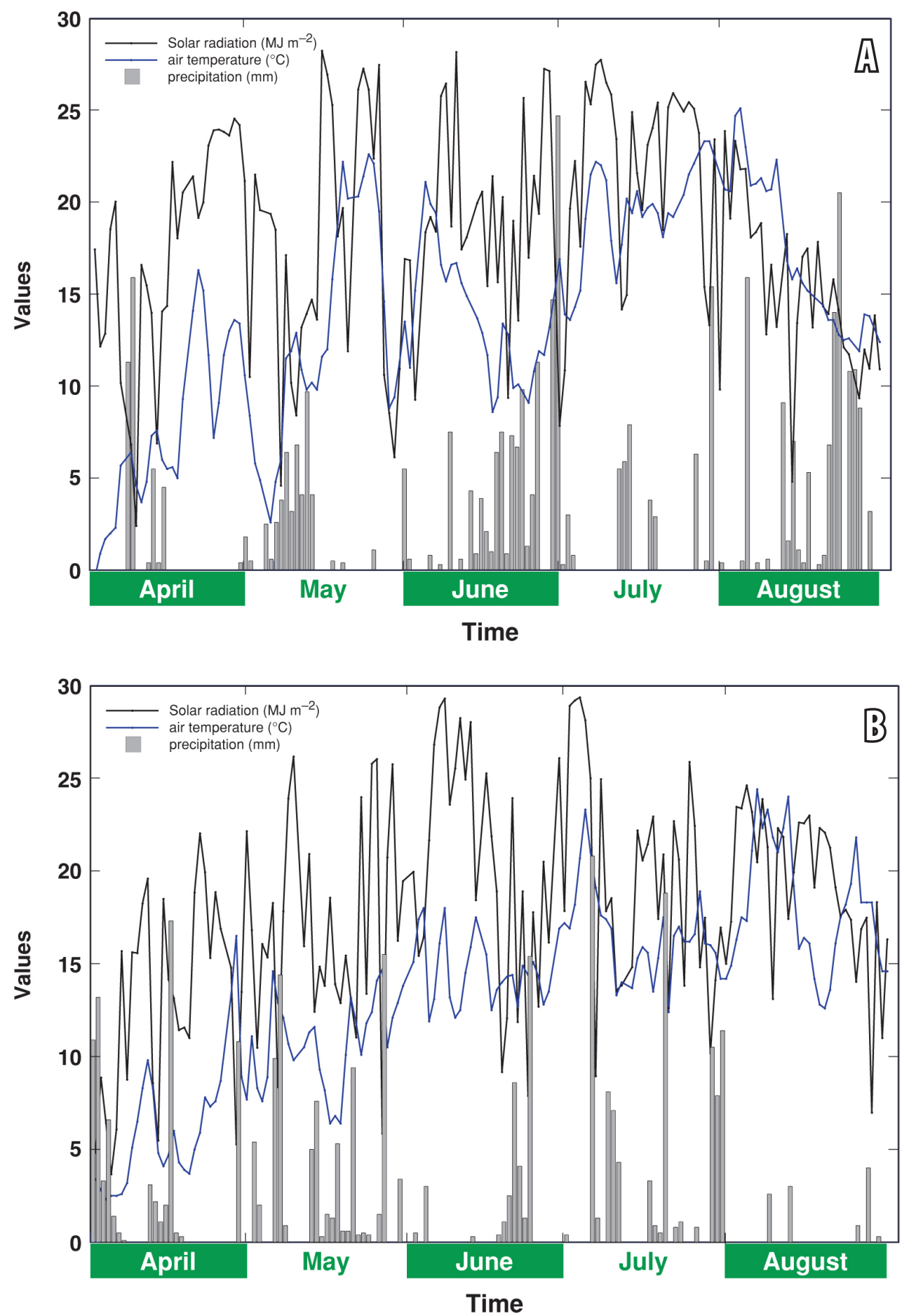

Fig. 2. Changes of air temperature $\left(\mathrm{T},{ }^{\circ} \mathrm{C}\right)$, amount of precipitation $(\mathrm{N}, \mathrm{mm})$ and intensity of solar radiation $\left(\mathrm{R}, \mathrm{MJ} \mathrm{m}^{-2}\right)$ during the studied moss sampling period in 2014 (A) and 2015 (B).

increased precipitation, concentration of carbohydrates as well as polyphenols in three studied moss species increased (P. schreberi, S. fallax, S. magellanicum), while in $P$. juniperinum polyphenol concentration decreased, and that of carbohydrates increased. For $P$. juniperinum and $P$. schreberi the increase of both total polyphenol and total carbohydrate concentration in 2014 season coincided with increased precipitation. However, for S. fallax and $S$. magellanicum, growing in microhabitats with increased humidity, the relationship with precipitation was not so well expressed. In 2015, when the climatic conditions were less variable, concentration of polyphenols and carbohydrates showed smaller changes, supporting dependence of both primary and secondary metabolism on climatic conditions. 

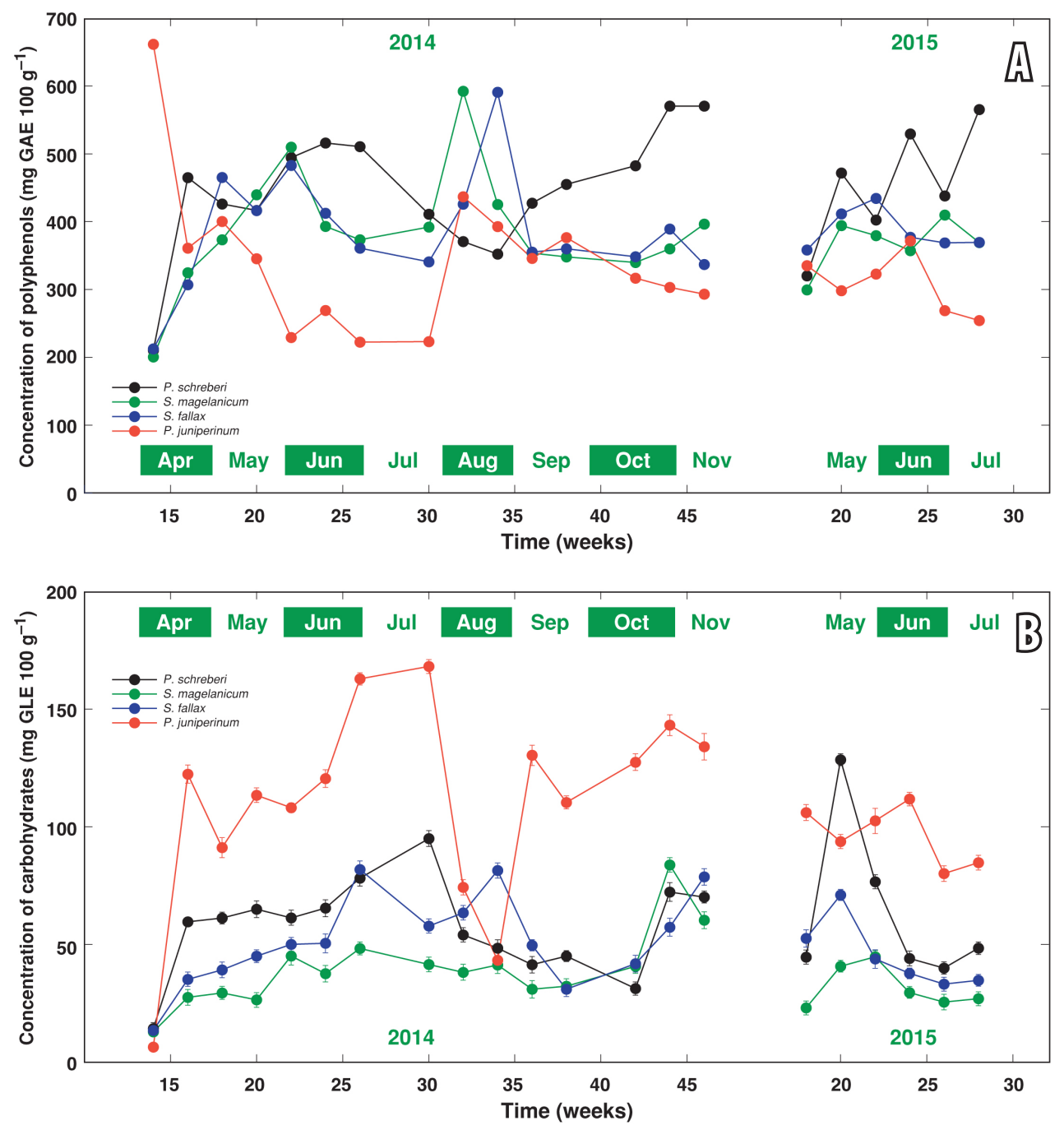

Fig. 3. Changes of total polyphenol (A) and carbohydrate (B) concentration in the studied moss tissues during the study period.

Strong correlation were found between the climatic parameters (sampling time, temperature and precipitation) during the study period and several chemical characteristics of moss extracts (Table 1). Total yield of extracted substances (as indicated by the amount of dry residue) correlated with amount of precipitation. UV sorption intensity of the extracts was a species-specific parameter and also negatively correlated with its radical scavenging activity. Radical scavenging activity was strongly dependent on moss species and sampling season. In general, radical scavenging activity was highest at the start of the vegetation season, decreasing gradually afterwards (data not shown). Concentration of flavonoids correlated with concentration of total polyphenols.

The influence of seasonal processes on composition of secondary metabolites was further studied for lipids (not only triglycerides, but also waxes, fatty acids and alcohols, sterols, terpenes and other polar substances). Pattern of their changes becomes evident from results of chromatographic analysis of lipids from S. fallax tissues (Fig. 4, Table 2).
Visual evaluation of chromatograms revealed major differences both in location of chromatographic peaks and their intensity in different seasons. In all seasons, both saturated and unsatured carboxylic acids (peaks 20 to 33) constituted essential elements of lipid profiles. However, concentration of (Z,Z,Z) 9,12,15-octadecatrienoic acid (peak No. 25) significantly increased during the vegetation season. A significant group of moss secondary metabolites was phytosterols (substances No. 50 to 57). Also phytosterols were found in all seasons of vegetation period with slightly changing proportions. Largest diversity and highest concentration of phytosterols were found in autumn season, and lowest in summer season during drier periods.

Chromatographic analysis revealed significant differences in the composition of the lipid fraction depending on the moss species (Fig. 4, Table 2) and sampling season, as demonstrated for $S$. fallax. The most abundant group of lipids in moss were fatty acids (329 to $1707 \mathrm{mg}$ per $100 \mathrm{~g}$ dry moss) and sterols (632 to $2130 \mathrm{mg}$ per $100 \mathrm{~g}$ dry moss). 
Table 1. Correlation between changes of climatic parameters and composition indicators of studied mosses during the study period (Kendall tau correlation). AA, antioxidant activity; PD, total polyphenolic concentration; FD, total flavonoid concentration; SI, dry residue of extracts; UV, sorption of extracts at $280 \mathrm{~nm} .{ }^{* *}$, significant correlation at the 0.01 level (1-tailed). ${ }^{*}$, significant correlation at the 0.05 level (1-tailed)

\begin{tabular}{|c|c|c|c|c|c|c|c|c|c|}
\hline & Temperature & Precipitation & Month & Type & AA & PD & OD & FD & SI \\
\hline Precipitation & $-0.257^{\star *}$ & & & & & & & & \\
\hline Month & -0.050 & -0.050 & & & & & & & \\
\hline AA & -0.131 & 0.018 & $-0.217^{*}$ & $0.693^{* *}$ & & & & & \\
\hline PD & 0.136 & -0.016 & -0.011 & 0.042 & 0.017 & & & & \\
\hline OD & 0.120 & -0.011 & $0.155^{*}$ & $-0.387^{\star *}$ & $-0.546^{* *}$ & -0.102 & & & \\
\hline FD & 0.009 & 0.035 & 0.086 & -0.043 & -0.035 & $0.273^{\star *}$ & -0.077 & & \\
\hline SI & -0.097 & $0.211^{\star}$ & 0.136 & $0.278^{\star *}$ & 0.140 & 0.021 & 0.085 & 0.122 & \\
\hline UV & -0.011 & 0.064 & 0.008 & $-0.649^{\star *}$ & $-0.682^{* *}$ & -0.017 & $0.463^{\star *}$ & 0.018 & -0.141 \\
\hline
\end{tabular}
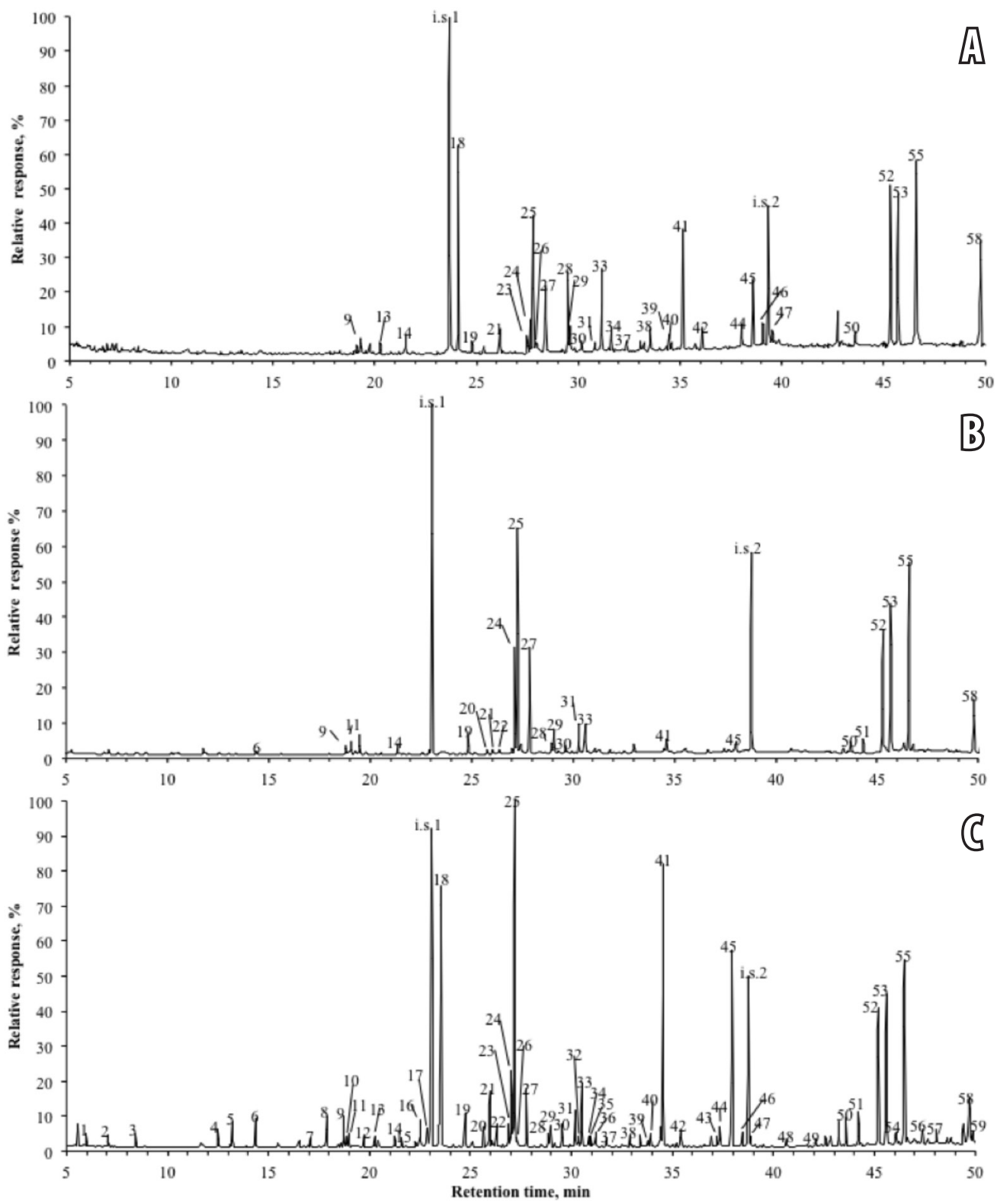

Fig. 4. Gas chromatogram with mass-spectrometric detection of the lipid extract of Sphagnum fallax in spring (A, 07.04.2014), summer (B, 23.07.2014), and autumn (C, 25.10.2014). i.s.1, internal standard methyl hexadecanoate; i.s.2, internal standard progesterone. Peak numbers refer to compounds listed in Table 4. Acid and alcohol groups were derivatised prior to GC/MS analysis 
Analysis of freely available lipids (Table 2) revealed a high number of different groups of substances. Significant qualitative and quantitative differences were found between studied moss species in respect to lipid composition: many substances like sterols and terpenoids were quantified only in some moss species and this particularity is relevant in respect to the biologically most active substances. In $S$. magellanicum high concentration of abietic acid and $\beta$-sitosterol was found, while in P. juniperinum other sterols were found in comparatively higher concentrations than in other mosses. The highest number of lipid-like substances was found in P. shreberi and the lowest in S. magelanicum. Tissues of the studied moss species contained a significant number of alkanes and fatty acids, including many unsaturated fatty acids and fatty alcohols.

However concentrations of moss lipids dependended on the season, thus reflecting pattern of their biosynthesis and decomposition during the vegetation period (Fig. 5, 6). All selected lipid class representatives (campesterol, stigmasterol, $\beta$-sitosterol, betulin, octadecanoic acid, pimaric acid, sandaracopimaric acid, and dehydroabietic acid) had a seasonal pattern for their concentration, with a maximum at time of most intensive growth in June and July, gradually decreasing towards autumn. However, for different moss species maximal concentration was seen at different times, indicating differences in biosynthetic processes (Fig. 6).

\section{Discussion}

Any seasonal pattern of chemical constituent concentration in bryophyte tissues is a result of both genetically

Table 2. Concentration of metabolites ( $\mu \mathrm{g}$ per $100 \mathrm{mg}$ dry weigth) in tissues of Sphagnum fallax (SF), Sphagnum magellanicum (SM), Polytrichum juniperinum (PJ), Pleurozium schreberi (PS). Peak numbers as in Fig. 2. Sampling season: summer (23.07.2014). RT, retention time; RI, retention index calculated as in Svein 2004. a, retention time in semi-standard non-polar column Elite-5MS. b, results of the retention index measurements are given with standard deviation \pm 2 . n.r., compound was not registered

\begin{tabular}{|c|c|c|c|c|c|c|c|c|}
\hline Peak No. & $\mathrm{RT}^{\mathrm{a}}(\min )$ & $\mathrm{RI}^{\mathrm{b}}$ & Compounds & $\begin{array}{l}\text { Molecular } \\
\text { ion, } \mathrm{m} / \mathrm{z} \\
(\mathrm{TMS} \text { deriv. } \\
{[\mathrm{M}-15]^{+} \text {) }}\end{array}$ & SF & PS & SM & PJ \\
\hline \multicolumn{9}{|l|}{ Alcohols } \\
\hline 1 & 5.97 & 1178 & 1-Octanol & $202(187)$ & 11 & 11 & 64 & 104 \\
\hline 2 & 7.04 & 1266 & Glycerol & $308(293)$ & 31 & 28 & 29 & n.r. \\
\hline 4 & 12.49 & 1573 & 1-Dodecanol & $258(243)$ & 28 & 15 & 15 & 144 \\
\hline 7 & 17.08 & 1772 & 1-Tetradecanol & $286(271)$ & 5 & 8 & 12 & 25 \\
\hline 15 & 21.59 & 1965 & 1-Hexadecanol & 314 (299) & 16 & 14 & 7 & 15 \\
\hline 21 & 25.96 & 2159 & 1-Octadecanol & $342(327)$ & 512 & 315 & 39 & 176 \\
\hline 39 & 33.8 & 2551 & Docosanol & $398(383)$ & 27 & 24 & 33 & 76 \\
\hline 48 & 40.65 & 2949 & 1-Hexacosanol & 454 (439) & 17 & n.r. & 32 & n.r. \\
\hline \multicolumn{9}{|l|}{ Alkanes } \\
\hline 5 & 13.23 & 1607 & Hexadecane & 226 & 76 & 21 & 4 & 99 \\
\hline 8 & 17.88 & 1800 & Octadecane & 254 & 113 & 56 & 11 & 233 \\
\hline 16 & 22.53 & 2000 & Eicosane & 282 & 163 & 93 & 20 & 279 \\
\hline 19 & 24.75 & 2100 & Heneicosane & 296 & 258 & 48 & 135 & 31 \\
\hline 23 & 26.9 & 2200 & Docosane & 310 & 113 & 65 & 12 & 175 \\
\hline 29 & 28.96 & 2300 & Tricosane & 324 & 230 & n.r. & 93 & n.r. \\
\hline 35 & 30.97 & 2400 & Tetracosane & 338 & 48 & 25 & 7 & 154 \\
\hline 38 & 32.9 & 2500 & Pentacosane & 352 & 44 & 31 & 64 & 15 \\
\hline \multicolumn{9}{|l|}{ Acids } \\
\hline 3 & 8.42 & 1359 & Nonanoic acid & $230(215)$ & 11 & 16 & 25 & 7 \\
\hline 6 & 14.35 & 1657 & Dodecanoic acid & $272(257)$ & 82 & 16 & 10 & 24 \\
\hline 11 & 18.98 & 1853 & Tetradecanoic acid (myristic acid) & $300(285)$ & 69 & 50 & 42 & 15 \\
\hline 14 & 21.26 & 1949 & Pentadecanoic acid & $314(299)$ & 100 & 49 & 46 & 59 \\
\hline 17 & 22.88 & 2020 & (Z) 9-Hexadecenoic acid & $326(311)$ & 96 & 143 & 100 & 40 \\
\hline 18 & 23.54 & 2050 & Hexadecanoic acid (palmitic acid) & $328(313)$ & 5541 & 4033 & 5083 & 4354 \\
\hline 20 & 25.66 & 2145 & Heptadecanoic acid (margaric acid) & $342(327)$ & 33 & 17 & 54 & 7 \\
\hline 24 & 27.04 & 2210 & (Z,Z) 9,12-Octadecadienoic acid & $352(337)$ & 673 & 137 & 708 & 6 \\
\hline
\end{tabular}

continued 
Table 2. continued

\begin{tabular}{|c|c|c|c|c|c|c|c|c|}
\hline Peak No. & $\mathrm{RT}^{\mathrm{a}}(\mathrm{min})$ & $\mathrm{RI}^{\mathrm{b}}$ & Compounds & $\begin{array}{l}\text { Molecular } \\
\text { ion, } \mathrm{m} / \mathrm{z} \\
(\mathrm{TMS} \text { deriv. } \\
\left.[\mathrm{M}-15]^{+}\right)\end{array}$ & SF & PS & SM & PJ \\
\hline 25 & 27.2 & 2217 & $\begin{array}{l}(\mathrm{Z}, \mathrm{Z}, \mathrm{Z}) \text { 9,12,15-Octadecatrienoic } \\
\text { acid }\end{array}$ & $350(335)$ & 3292 & 603 & 2947 & 118 \\
\hline 26 & 27.34 & 2224 & $\begin{array}{l}\text { (E) 9-Octadecenoic acid (elaidic } \\
\text { acid) }\end{array}$ & $354(339)$ & 72 & 47 & 64 & 37 \\
\hline 27 & 27.78 & 2246 & Octadecanoic acid (stearic acid) & $356(341)$ & 529 & 696 & 382 & 134 \\
\hline 31 & 30.2 & 2365 & $\begin{array}{l}\text { (all-Z) 5,8,11,14-Eicosatetraenoic } \\
\text { acid }\end{array}$ & $376(361)$ & 394 & 320 & 361 & 67 \\
\hline 32 & 30.36 & 2372 & (all-Z) 8,11,14-Eicosatrienoic acid & $374(359)$ & 21 & 112 & n.r. & 42 \\
\hline 37 & 31.74 & 2441 & Eicosanoic acid (arachidic acid) & $384(369)$ & 60 & 68 & 42 & 37 \\
\hline 42 & 35.43 & 2639 & Docosanoic acid (behenic acid) & $412(397)$ & 132 & 63 & 93 & 16 \\
\hline 43 & 37.21 & 2735 & Tricosanoic acid & $426(4110$ & 36 & n.r. & 18 & 38 \\
\hline 47 & 38.86 & 2837 & Tetracosanoic acid (lignoceric acid) & $440(425)$ & 76 & 38 & 59 & n.r. \\
\hline 49 & 42.11 & 3041 & Hexacosanoic acid (ceratinic acid) & $468(453)$ & 13 & 110 & 21 & 7 \\
\hline \multicolumn{9}{|c|}{ 然 } \\
\hline 34 & 30.86 & 2397 & 2,3-Dihydroxypropyl tetradecanoate & $446(4310$ & 55 & 42 & 3 & 9 \\
\hline 40 & 33.91 & 2557 & $\begin{array}{l}\text { 2-Hydroxy-1-(hydroxymethyl)ethyl } \\
\text { hexadecanoate }\end{array}$ & $474(459)$ & 103 & 133 & 31 & 7 \\
\hline 41 & 34.55 & 2594 & 2,3-Dihydroxypropyl hexadecanoate & $474(459)$ & 2584 & 1777 & 177 & 664 \\
\hline 44 & 37.35 & 2744 & $\begin{array}{l}\text { 2-Hydroxy-1-(hydroxymethyl)ethyl } \\
\text { octadecanoate }\end{array}$ & $502(487)$ & 147 & 191 & 66 & 51 \\
\hline 45 & 37.96 & 2781 & 2,3-Dihydroxypropyl octadecanoate & $502(487)$ & 1790 & 1111 & 119 & 210 \\
\hline 59 & 50.01 & 3552 & Phytylhexadecanoate & 534 & 134 & 238 & 43 & 31 \\
\hline \multicolumn{9}{|l|}{ Terpenes } \\
\hline \multirow[t]{2}{*}{9} & 18.73 & 1842 & Neophytadiene & & & & & \\
\hline & 278 & 136 & 142 & 200 & 18 & & & \\
\hline 10 & 18.84 & 1846 & Hexahydrofarnesyl acetone & 268 & 19 & 11 & 12 & 3 \\
\hline 12 & 19.72 & 1884 & Phyta-1,3(E)-diene & 278 & 38 & 60 & 78 & 5 \\
\hline 22 & 26.29 & 2174 & Phytol & $368(353)$ & 199 & 297 & 751 & 135 \\
\hline 28 & 28.85 & 2298 & Pimaric acid & $374(359)$ & 151 & 329 & 143 & 66 \\
\hline 30 & 29.54 & 2331 & Isopimaric acid & $374(359)$ & 194 & 402 & 176 & 52 \\
\hline 33 & 30.53 & 2381 & Dehydroabietic acid & $372(357)$ & 500 & 900 & 522 & 61 \\
\hline 36 & 31.22 & 2415 & Abietic acid & $374(359)$ & 89 & 89 & 228 & n.r. \\
\hline 46 & 38.45 & 2811 & Squalene & 410 & 111 & 265 & 131 & 55 \\
\hline 58 & 49.84 & 3543 & Betulin & $586(571)$ & 11 & 102 & 82 & 16 \\
\hline \multicolumn{9}{|c|}{ Phytosteroles } \\
\hline 50 & 43.6 & 3136 & $\alpha$-Tocopherol + Cholesterol & $\begin{array}{l}502(487) ; 458 \\
(443)\end{array}$ & 159 & 133 & 197 & 25 \\
\hline 51 & 44.23 & 3175 & $\begin{array}{l}\text { Campesta-5,22E-dien-3 } \beta \text {-ol } \\
\text { (24-epibrassicasterol) }\end{array}$ & $470(455)$ & 5 & 22 & 26 & 3 \\
\hline 52 & 45.19 & 3236 & Campesterol & $472(457)$ & 46 & 260 & 113 & 51 \\
\hline 53 & 45.6 & 3261 & Stigmasterol & $484(469)$ & 44 & 155 & 123 & 86 \\
\hline 54 & 46.07 & 3291 & Ergost-7-en-3-ol ( $\gamma$-ergostenol) & $472(457)$ & 1 & n.r. & 2 & n.r. \\
\hline 55 & 46.48 & 3319 & $\beta$-Sitosterol & $486(471)$ & 62 & 248 & 273 & 34 \\
\hline 56 & 47.39 & 3384 & Cycloartenol & $498(483)$ & 1 & 74 & 9 & 6 \\
\hline 57 & 48.08 & 3432 & $\gamma$-Sitostenone & 412 & 1 & 28 & 11 & 1 \\
\hline \multicolumn{9}{|c|}{ Oxygen-heterocycles } \\
\hline 13 & 20.27 & 1909 & $\begin{array}{l}\text { 7,9-Ditertbutyl-1-oxaspiro[4.5]deca- } \\
\text { 6,9-diene-2,8-dione }\end{array}$ & 276 & 40 & 105 & 11 & 42 \\
\hline
\end{tabular}




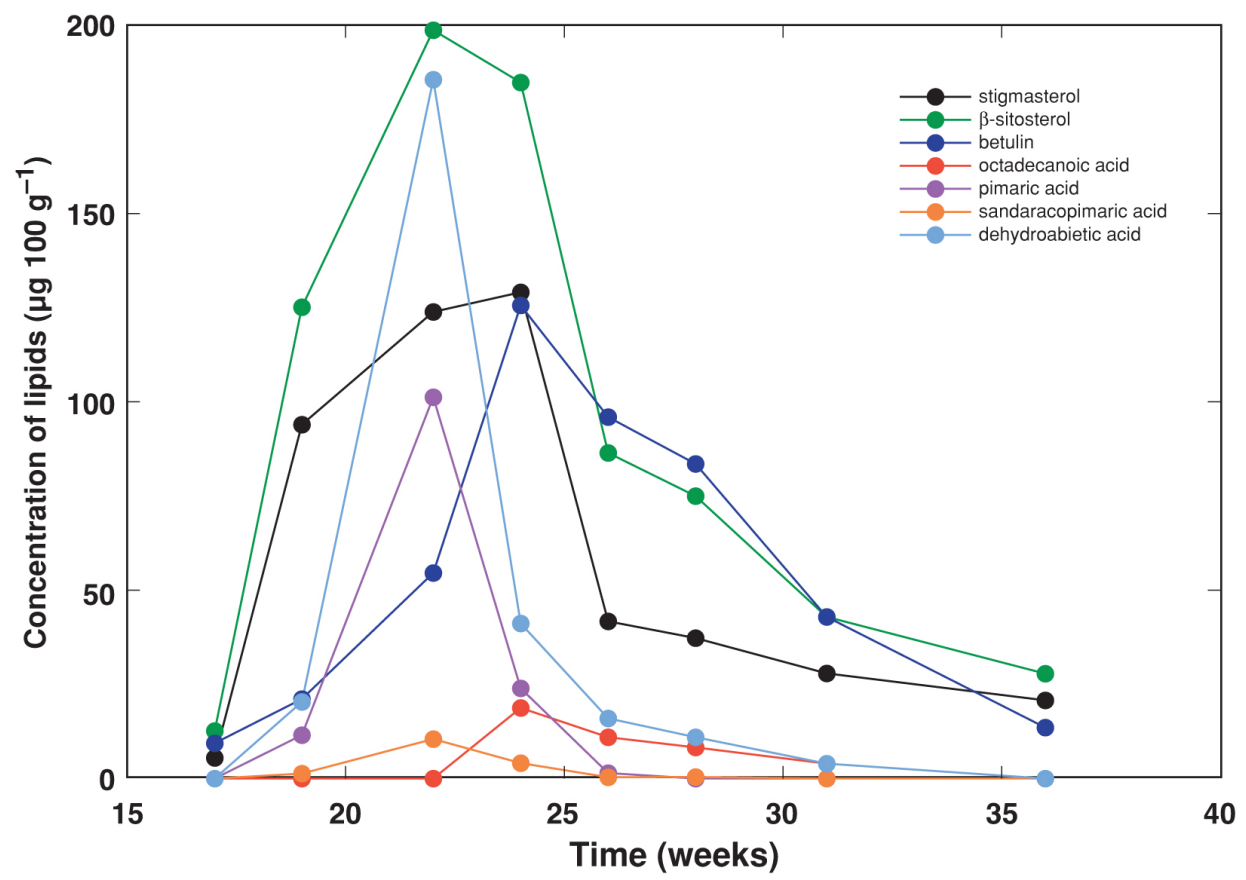

Fig. 5. Changes of lipid concentration in the extract of Sphagnum fallax. Lipid analysis was performed by GC/MS after sample derivatisation.

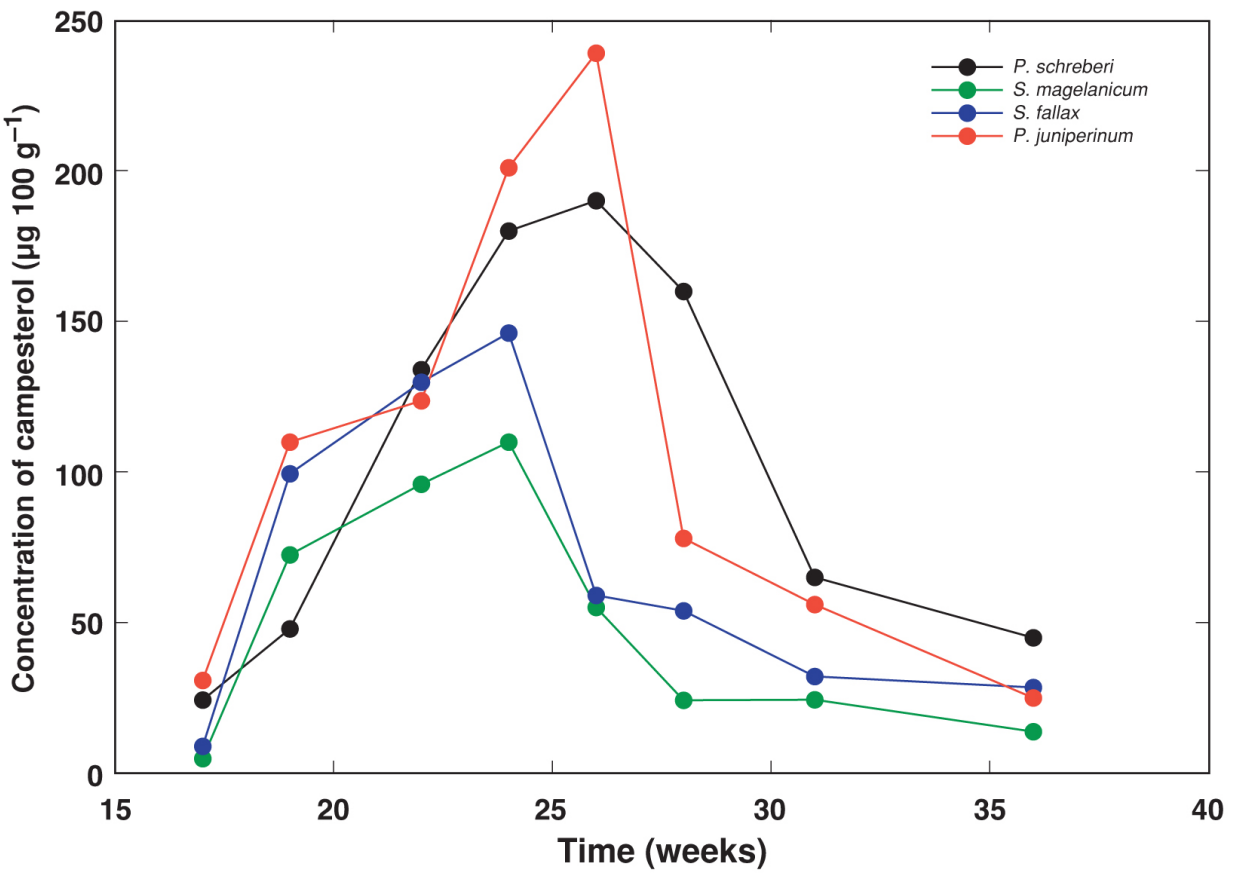

Fig. 6. Changes of campesterol concentration in Sphagnum fallax, Sphagnum magellanicum, Polytrichum juniperinum, Pleurozium schreberi. Campesterol analysis was performed by GC/MS after sample derivatisation.

determined developmental signals as well as more direct effect of changes in environmental parameters. Amongst environmental processes affecting chemical composition of plants, climatic factors might be considered to have primary position. Seasonal differences in growth intensity can account for a majority of changes in chemical constituents related to primary as well as secondary metabolism.
It is usually assumed that vegetative growth of bryophytes occurs mostly in spring and early summer, and, at least for some species, in late autumn, while summer growth is restricted due to water shortage (Hájek 2014). However the generalisation of the findings of this study is not relevant for growth conditions of bryophytes in most of their distribution regions. Wetter 
microhabitats, as those of several Sphagnum species, allow for longer growth periods (Hulme, Blyth 1982). Seasonal timing of maximum photosynthesis, as a process resulting in producing carbohydrates, does not necessarily coincideswith maximum growth rate due to differences in resource allocation (Hájek 2014). In general, higher concentrations of carbohydrates indicate higher metabolic activity in moss of wet habitats (Pakarinen, Vitt 1975). However, high concentration of soluble carbohydrates in winter can indicate their role in cellular osmoprotection as a mechanism against freezing (Hájek 2014).

Carbohydrate concentration in the present study showed increasing but species-specific trend from spring to summer, with a characteristic decrease in autumn (Fig. 3B). In contrast, no season-dependent differences in carbohydrate concentration were found in a number of Antarctic bryophyte species (Melick, Seppelt 1994), which was explained by a relatively highly fluctuating temperature and other climate variables. Both spatial and temporal differences in carbohydrate concentration might be associated with fluctuations in water availability in the particular microhabitat, as it has been shown that moss species from more hydric habitats have lower total carbohydrate concentration in comparison to these from drier habitats (Davey 1999). This is in opposite to the present observation that carbohydrate concentration increased during a period of increased precipitation, probably reflecting species-specific features, but also differences in analytical methods used.

In bryophytes carbohydrates have reserve and structural functions, lignin is nearly absent, and lipids belong to reserve substances. High amounts of acyl lipids are accumulated in chloroplast membranes of photosynthetically-competent tissues. Thus, photosynthetically active parts of Sphagnum fuscum are characterized by the highest total lipid values, including membrane-associated acyl lipids (Karunen, Salin 1982).

Decrease of lipid concentration, in particular, that of triglycerides, was observed with start of growth of shoot apex in Sphagnum fuscum, indicating decrease in storage compounds (Karunen, Salin 1982). In Himalayan liverworts, accumulation of carbohydrates started towards the end of the growing season, reaching highest concentration in a dormant period (Thakur, Kapila 2016).

Analysis of freely available lipids (Table 2) showed a high number of different groups of substances (altogether 59 different substances were identified and quantified in the studied mosses) playing significant functions in moss metabolism and possibly affecting the biological activity of their extracts. There were significant differences amongst studied moss species: many substances have been quantified only in some moss species and this is relevant with respect to biologically most active substances, like sterols and terpenoids. In P. commune other sterols were found in comparatively higher concentrations than in other mosses. The highest number of substances was found in P. shreberi, and the lowest in S. magellanicum. For first time in mosses the following substances were identified: diploptene, $a$-amyrin, oleanolic acid, uvaol, cycloartenol, ursolic acid, neophytadiene and others. The studied mosses contained a significant number of alkanes and fatty acids, including many unsaturated fatty acids and fatty alcohols.

High concentrations of polyunsaturated long-chain fatty acids are a characteristic feature of bryophyte tissues (Gellerman et al. 1975). In Rhytididelphus squarrosus collected in winter, the most abundant (more than 10\%) identified fatty acids were arachidonic acid (30.7\%), linoleic acid (15.1\%), cis-5.8.11.14.17-eicosapentaenoic acid (14.4\%), and palmitic acid (11.9\%) (Pejin et al. 2011). Secondary metabolites (sterols and terpenoids) rise interest from perspective of bioprospecting. Secondary metabolites evidently have major regulatory functions in mosses. Their concentrations depends on the season. This finding is of utmost importance for selection of the season for analysis oof biologically active substances in the mosses, and especially if the metabolites are extracted for their application, for example, in biomedicine.

Phenolic compounds, especially flavonoids, are important in UVB absorption (Meijkamp et al. 1999). Dissipation of excessive light-associated energy in chloroplasts is due to protective features of carotenoids, and many bryophyte species respond to high UVB radiation by accumulation of protective substances (Robinson et al. 2005; Lappalainen et al. 2009). In S. fallax, total concentration of water-soluble phenolic substances was highest in spring and gradually decreased during the season with significantly lower concentration in autumn (Jassey et al. 2011). This characteristic trend was associated with increased temperature-associated decrease in moisture. In contrast, in the present study, both S. magelanicum and $S$. fallax showed increase of total polyphenol concentration in spring with a following decrease in June-July (Fig. 3A), when summary precipitation was extremely high (Fig. 2A).

Tocopherol can protect chlorophyll from degradation by stabilizing chlorophyll-complexing lipid, monogalactose glyceride, during colder conditions in spring and autumn (Kuiper 1978). Tocopherol concentration was relatively high in S. fallax, S. magelanicum and P. schreberi, but the concentration in $P$. juniperinum was significantly lower (Table 2) possibly reflecting functional differences related to adaptation to climatic conditions.

Radical scavenging activity was highest at the start of the vegetation season, decreasing gradually afterwards, while the trend of changes for carbohydrates was just opposite highest at the end of vegetation season. The concentrations (Fig. 5) of individual representatives of biologically active substances (secondary metabolites of mosses) increase at the start of the vegetation season and gradually decreases towards its end, thus reflecting active participation in the growth processes. Concentrations of some biologically 
active substances do not much react on rapid temperature and precipitation changes during the vegetation season and this pattern is common for all four studied mosses (Fig. 5). The seasonal pattern of concentration changes of moss composition and their secondary metabolites, and especially lipids, is important to understand regulation processes in mosses and bryophytes in general, and thus provdie insight on metabolic regulation in plants at early stages of their development.

Main practical implications of the study are related to selection of the sampling seasons for bioprospecting studies to study and isolate biologically active substances present in mosses. The most appropriate season for bioprospecting and secondary metabolism studies can be considered autumn. However, effect of precipitation and other climatic conditions on the secondary metabolite composition should be considered, an aspect fully ignored until now. Significant dependence of the moss secondary metabolism on climatic conditions can help to understand and forecast climate change impacts

\section{References}

Asakawa Y., Ludwiczuk A., Nagashima F. 2013. Chemical Constituents of Bryophytes: Bio- and Chemical Diversity, Biological Activity, and Chemosystematics. Springer, New York, $796 \mathrm{p}$.

Boquette M.T., Fernandez J.A., Aboal J.R., Carballeira A. 2011. Analysis of temporal variability in the concentrations of some elements in the terrestrial moss Pseudoscleropodium purum. Environ. Exp. Bot. 72: 210-215.

Cheng X., Xiao Y., Wang X., Wang P., Li H., Yan H., Liu Q. 2012. Anti-tumor and pro-apoptic activity of ethanolic extract and its various fractions from Polytrichum commune L. Ex Hedw in L1210 cells. J. Ethnopharmacol. 143: 49-56.

Davey M.C. 1999. The elemental and biochemical composition of bryophytes from the maritime Antarctic. Antarctic Sci. 11: 157-159.

Fu P., Lin S., Shan L., Lu M., Shen Y.H., Tang J., Liu R.H., Zhang X., Zhu R.L., Zhang W.D. 2012. Constituents of the moss Polytrichum commune. J. Nat. Prod. 72: 1335-1337.

Gellerman J.L., Anderson W.H., Richardson D.G., Schlenk H. 1975. Distribution of arachidonic and eicosapentaenoic acid in the lipids of mosses. Biochim. Biophys. Acta 338: 277-290.

Goffinet B., Shaw A.J. 2008. Bryophyte Biology. Cambridge University Press, Cambridge, 565 p.

Hájek T. 2014. Physiological ecology of peatland bryophytes. In: Hanson D.T., Rice S.K. (eds) Photosynthesis in Bryophytes and Early Land Plants. Springer, Dordrecht, pp. 233-252.

Hulme P.D., Blyth A.W. 1982. The annual growth period of some Sphagnum species on the Silver Flowe National Nature Reserve, south-west Scotland. J. Bryol. 12: 287-291.

Jassey V.E.J., Chiapusio G., Gilbert D., Buttler A., Toussaint
M.L., Binet P. 2011. Experimental climate effect on seasonal variability of polyphenol/phenoloxidase interplay along a narrow fen-bog ecological gradient. Global Change Biol. 17: 2945-2957.

Karunen P., Salin M. 1982. Seasonal changes in lipids of photosynthetically active and senescent parts of Sphagnum fuscum. Lindbergia 8: 35-44

Klavina L. 2015. Polysaccharides from lower plants: bryophytes. In: Ramawat K.G., Mérillon J.-M. (eds) Polysaccharides. Springer International Publishing, Switzerland.

Klavina L., Kviesis J. 2015. Solid phase extraction of bryophyte lipids. Mater. Sci. Appl. Chem. 32: 58-67.

Kuiper P.J.C. 1978. Mechanisms of adaptation to physical and chemical factors in plants. In: Freysen A.H.J., Woldendrop J.W. (eds) Structure and Functioning of Plant Populations. NorthHolland Publishing, New York, pp. 215-235.

Lappalainen N.M., Huttunen S., Suokanerva H., Lakkala K. 2009. Seasonal acclimation of the moss Polytrichum juniperinum Hedw. to natural and enhanced ultraviolet radiation. Environ. Pollut. 158: 891-900.

Maksimova V., Klavina L., Bikovens O., Zicmanis,A., Purmalis O. 2013. Structural characterization and chemical classification of some bryophytes found in Latvia. Chem. Biodiv. 10: 12841294.

Meijkamp B., Aerts R., Van de Staaij J., Tosserams M., Ernst W.H.O., Rozema J. 1999. Effects of UV-B on secondary metabolites in plants. In: Rozema J. (ed) Stratospheric Ozone Depletion, the Effects of Enhanced UV-B Radiation. Backhuys Publishers, Leiden, pp. 71-99.

Melick D.R., Seppelt R.D. 1994. Seasonal investigations of soluble carbohydrates and pigment levels in Antarctic bryophytes and lichens. Bryologist 97: 13-19.

Pakarinen P., Vitt D.H. 1975. The major organic components and caloric contents of high arctic bryophytes. Can. J. Bot. 52: 1151-1161.

Pejin B., Vujisić L., Sabovljević A., Sabovljević M., Tešević V., Vajs V.2011. An insight into fatty acid chemistry of Rhytididelphus squarrosus (Hedw.) Warnst. Bot. Serbica 35: 99-101.

Robinson S.A., Turnbull J.D., Lovelock C.E. 2005. Impact of changes in natural ultraviolet radiation on pigment composition, physiological and morphological characteristics of the Antarctic moss, Grimmia antarctici. Global Change Biol. 11: 476-489.

Svein A.M. 2004. Two-dimensional fatty acid retention indices. J. Chromatogr. A 1061: 201-209.

Thakur S., Kapila S. 2016. Seasonal changes in the storage compounds and enzymatic activities in three Indian leafy liverworts. Biolife 4: 605-612.

Xianyu H., Jiantao X., Jinxiang Z., Yangmin Q., Philip A.M., Hongmei W. 2012. Effect of different wetness conditions on Sphagnum lipid composition in the Erxianyan peatland, central China. Org. Geochem. 44: 1-7.

Xie C.F., Lou H.X. 2009. Secondary metabolites in bryophytes: an ecological aspect. Chem. Biodiv. 6: 303-312. 